\title{
Multiple myeloma mimicking primary bone tumour
}

\author{
Satyaranjan Das, ${ }^{1}$ Uday Yanamandra 다. , Schezan Iqbal, ${ }^{2}$ Rajan Kapoor ${ }^{1}$
}

${ }^{1}$ Department of Hematology and Stem Cell transplant, Army Hospital Research and Referral, New Delhi, India

${ }^{2}$ Department of Orthopedics, Armed Forces Medical College, Pune, Maharashtra, India

\section{Correspondence to} Dr Uday Yanamandra; udayj2@gmail.com

Accepted 25 September 2019

\section{DESCRIPTION}

A 42-year-old man presented with easy fatiguability, pain and swelling in the upper limbs of 6-month duration associated with progressive difficulty in bearing weights (figure 1). Imaging revealed extensive ill-defined osteolytic lesions of both humerus which are permeative, with a wide zone of transition, the absence of a definite sclerotic margin with an aggressive periosteal reaction and cortical breakthroughs with extensive soft tissue involvement suggestive of highly aggressive malignant bone lesion (figure 2A,B). They also do not show a definite predilection for diaphyseal, metaphyseal or epiphysial sites. Keeping in view the unusual presentation of multiple bony lesions in a middle-aged male, the possibilities of synchronous multifocal osteosarcoma, chronic recurrent multifocal osteomyelitis (CRMO), synchronous multifocal giant cell tumour (MGCT), metastases from primary sites and multifocal chondrosarcoma were considered. Bone biopsy of the lesions revealed sheets of plasma cells, suggesting multiple myeloma which was later confirmed by the presence of monoclonal plasma cells in bone marrow and serum $\mathrm{M}$ spike with raised free light chains. Positron emission tomography (PET) scan revealed high Fluorodeoxyglucose (FDG) avidity (SUVmax-10.2) in these lesions. He was started on bortezomib-based chemotherapy (Bortezomib, cyclophosphamide and dexamethasone regimen) and radiotherapy to involved lesions for pain relief but succumbed to his illness due to rapidly evolving renal failure secondary to the primary disease.

Synchronous multifocal osteosarcoma is characterised by tumorous lesions in multiple osseous sites in the absence of pulmonary metastases. ${ }^{1}$ In our case, this diagnosis is unlikely since the patient is a middle-aged male and the radiographs have central lesions which do not reveal the

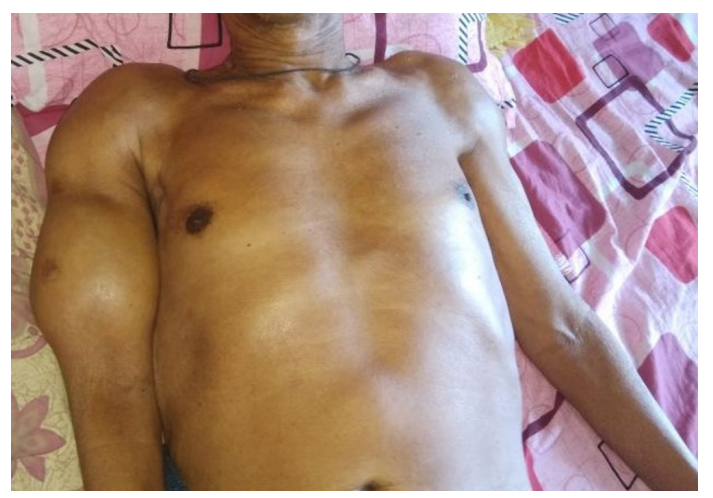

Figure 1 Image depicting bilateral shoulder swelling and swelling of the right arm.

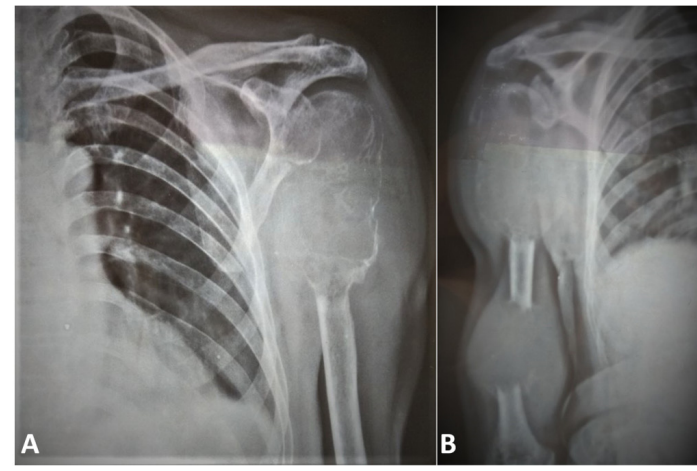

Figure 2 X-rays of the left (A) and right (B) shoulder/ arm revealing bilateral ill-defined osteolytic lesions with a wide zone of transition, absent sclerotic margin, aggressive periosteal reaction and cortical breakthrough with extensive soft tissue involvement.

classical periosteal reaction with formation of the Codman's triangle nor any 'sunburst' appearance. CRMO is usually seen in children or adolescents, and lesions typically reveal multiple lytic, mixed or pure sclerotic lesions which may be associated with palmoplantar pustulosis. ${ }^{2}$ In a middle-aged male with no clinical features of definitive infection, along with no radiological evidence of any sequestrum or sinuses, CRMO seems unlikely. Radiological findings of MGCT include radiolucent, eccentric, expansile lesions in the metaphyseal-diaphyseal region. This entity was ruled out considering its rarity $(<1 \%$ of all Germ cell tumors), predilection in young, and X-ray showing no periosteal reaction and a narrow transition zone. ${ }^{3}$ Metastases from primary sites are more common in the axial skeleton and have characteristic features based on the primary malignancy (viz sclerotic-prostate $\mathrm{Ca}$; lytic-adenocarcinomas; lytic, solitary, bubbly-Ca thyroid). Radiographic presentation of index case is unlikely to be due to metastases, as the lesions are multiple and have a predominantly mixed appearance with predominance in the appendicular skeleton.

\section{Learning points}

Lytic lesions are present in $80 \%$ of myeloma patients at diagnosis.

- Delay in the diagnosis of myeloma can lead to severe skeletal-related events (fractures, osteolytic lesions) which can have direct adverse impact on survival and quality of life.

- Lytic lesions in multiple myeloma can rarely mimic primary bone tumour as in index case. 
The presentation of multiple myeloma with such radiological findings is infrequent. In the absence of bone marrow involvement, this case would have qualified for macro focal multiple plasmacytomas. ${ }^{4}$ Patients generally present late in real-world settings due to poor socioeconomic status and lack of education. ${ }^{5}$ We report a rare skeletal manifestation of multiple myeloma masquerading primary bone malignancy and such radiological phenomenon can lead to diagnostic delays.

Contributors SD, YU and RK were involved in the management of the patient. YU and SI were involved in the manuscript preparation. All authors have reviewed the manuscript prior to submission.

Funding The authors have not declared a specific grant for this research from any funding agency in the public, commercial or not-for-profit sectors.

Competing interests None declared.

Patient consent for publication Next of kin consent obtained.
Provenance and peer review Not commissioned; externally peer reviewed.

\section{ORCID iD}

Uday Yanamandra http://orcid.org/0000-0002-0546-6585

\section{REFERENCES}

1 Gupta M, Bahri N, Parekh H, et al. Synchronous multifocal osteogenic sarcoma on multimodality imaging including bone scintigraphy. Indian J Nucl Med 2014;29.

2 Jelušić M, Čekada N, Frković M, et al. Chronic Recurrent Multifocal Osteomyelitis (CRMO) and Synovitis Acne Pustulosis Hyperostosis Osteitis (SAPHO) Syndrome - Two Presentations of the Same Disease? Acta Dermatovenerol Croat 2018;26.

3 Murphey MD, Nomikos GC, Flemming DJ, et al. From the Archives of AFIP. imaging of giant cell tumor and giant cell reparative granuloma of bone: radiologic-pathologic correlation. Radiographics 2001;21:1283-309.

4 Sahu KK, Kumar PD, Yanamandra U, et al. Macrofocal multiple myeloma with frontal plasmacytoma. Case reports 2015;250:bcr2015210759.

5 Yanamandra U, Khattry N, Kumar S, et al. Consensus in the management of multiple myeloma in India at myeloma state of the art 2016 conference. Indian J Hematol Blood Transfus 2017;33:15-21.

Copyright 2019 BMJ Publishing Group. All rights reserved. For permission to reuse any of this content visit https://www.bmj.com/company/products-services/rights-and-licensing/permissions/

BMJ Case Report Fellows may re-use this article for personal use and teaching without any further permission.

Become a Fellow of BMJ Case Reports today and you can:

Submit as many cases as you like

Enjoy fast sympathetic peer review and rapid publication of accepted articles

- Access all the published articles

Re-use any of the published material for personal use and teaching without further permission

\section{Customer Service}

If you have any further queries about your subscription, please contact our customer services team on +44 (0) 2071111105 or via email at support@bmj.com.

Visit casereports.bmj.com for more articles like this and to become a Fellow 